Nr 2(59), 2019, s. 327-351

https://doi.org/10.12797/Politeja.16.2019.59.19

\author{
Martyna KOWALSKA (D) \\ Uniwersytet Jagielloński w Krakowie \\ martyna.z.kowalska@uj.edu.pl
}

\title{
REMAKE JAKO FORMA DIALOGU \\ Z KLASYKĄ (INSPIRACJE SZYNELEM \\ MIKOŁAJA GOGOLA W WYBRANEJ \\ LITERATURZE ROSYJSKIEJ XX I XXI W.)
}

ABSTRACT A Remake as a Form of Dialogue with the Classics (Nikolay Gogol's The Overcoat as an Inspiration in Russian Literature at the End of the $20^{\text {th }}$ Century and the Beginning of the $21^{\text {st }}$ Century)

The article is devoted to a very recent phenomenon in contemporary Russian literature - a remake. The subject of this research is the literary 'dialogue' between the classic short story of The Overcoat by Nikolay Gogol and Russian literary works at the end of the 20th century and the beginning of the 21 st century. In scope, there is a micro-novel of Vladimir Voinovich The Fur Hat, then Dmitry Gorchev's novel The Phone and Vladimir Shinkariev's work The Flat, as well as Bashmachkin - a drama written by Oleg Bogaev. The interest that contemporary authors demonstrate in Gogol's work is a result of the problems he described but which still appear to prevail. This is also an attempt to make Russian classics contemporary and reinterpret the 20th century novel simultaneously. The methods of bringing 'Gogol's text' up to date in the above-mentioned works present a wide range of possibilities that a remake offers. Voinovich put social and political principles of the Soviet state in the first place. The Table of Ranks together with its submission of an individual towards the state has been deeply analyzed. In Gorchev's and Shinkariev's stories, contemporary Bashmachkins 'little men', eager to fulfill their dreams about a better life - are presented. What is more, those texts show a very interesting picture of the Russian reality at the beginning of the 21 st century ruled by lawlessness, corruption and money. The most original approach to Gogol's work was presented by Bogaev in the continuation of the Bashmachkin's story, where the main character is actually the overcoat who is administering justice on behalf of a dying hero. The remake-sequel 
is not only a modernized version of Gogol's plot but also a new text emerging from a postmodern game. A proposed analysis of the above-mentioned Russian remakes presents many different ways a classic literature text can be modernized thanks to this kind of adaptation. However, on the ground of Russian literature, a remake is above all a pursuit of a dialogue with the classics, an attempt to modernize the problematic aspects and emphasize timeless contents.

Key words: remake, The Overcoat by N. Gogol, 'little men', postmodernism, literary theme, anthropology of things

Słowa kluczowe: remake, Szynel M. Gogola, „mały człowiek”, postmodernizm, motyw literacki, antropologia rzeczy

\section{siążki mówia zawsze o innych książkach i wszelka opowieść snuje historięuż opowie- Kdzianą ${ }^{1}$. Słowa Umberta Eco zawierają znaną prawdę i odnoszą się do kwestii te-} matycznej oryginalności tekstów literackich. Dla jednych twórców problem wtórności stał się powodem do buntu, prowadzącym do poszukiwań nowych zagadnień i rozwiązań stylistycznych. Inni ową powtarzalność akceptują, co więcej, czerpią z niej inspiracje. Pojmowanie rozwoju literatury jako dziedziczenia stało się szczególnie silne i świadome w XX wieku. Badania nad „dialogicznością” były przedmiotem refleksji Michaiła Bachtina. Niewątpliwie to właśnie rosyjski literaturoznawca skierował uwagę badaczy na ważność tej problematyki, dowodząc, że każdy utwór w jakiś sposób nawiązuje do innych tekstów, a słowo nigdy nie istnieje w izolacji, lecz zawsze odnosi się do poprzednich kontekstów² ${ }^{2}$ Dzięki Julii Kristevej, studiującej prace Bachtina, w 1967 roku do badań nad literaturą wszedł termin „intertekstualność” ${ }^{3}$, który szybko zrobił zawrotną karierę. Powołując się na Henryka Markiewicza, można podać, że najprostsza definicja intertekstualności brzmi: ujawnienie w samym tekście relacji do proto/arche/tekstu, sktaniajace do wzięcia go pod uwage $w$ recepcji tekstu $u^{4} \mathrm{Z}$ upływem lat pierwotne znaczenie pojęcia uległo dyferencjacjom i przekształceniom. Pojawiły się nowe określenia relacji międzytekstowych, wyznaczające szczególne formy zależności utworów, co Gérard Genette określa zbiorczo w swojej pracy jako transtekstualnośćs. Wielość stanowisk ba-

U. Eco, Dopiski na marginesie „Imienia róży”, [w:] tenże, Imię róży, przeł. A. Szymanowski, Warszawa 1987, s. 599.

2 Zob. M. Bahtin, Voprosy literatury i èstetiki. Issledovaniâ raznyh let, Moskva 1975.

3 Na temat intertekstualności zob. m.in. S. Balbus, Między stylami, Kraków 1996; J. Culler, Presupozycje i intertekstualność, przeł. K. Rosner, Warszawa-Wrocław 1980; G. Genette, Palimpsesty. Literatura drugiego stopnia, przeł. T. Stróżyński, A. Milecki, Gdańsk 2014; M. Głowiński, Intertekstualność, groteska, parabola. Szkice ogólne i interpretacje, Kraków 2000; H. Markiewicz, Odmiany intertekstualności, [w:] tenże, Literaturoznawstwo i jego sąiedztwa, Warszawa 1989, s. 198-228.

4 H. Markiewicz, Odmiany intertekstualności..., s. 215-216.

5 Genette wymienia pięć typów transtekstualności: intertekstualność, paratekstualność, metatekstualność, hipertekstualność, archetekstualność. G. Genette, Palimpsesty..., s. 7-13. 
dawczych nie pozwala na wyodrębnienie prostej i zadowalającej definicji. Dodatkowo postmodernizm, wyjątkowo chętnie czerpiący z „powtórzeń", wprowadził nowe określenia różnicujące charakter znanych już z przeszłości odniesień do innych dzieł 6 .

Jednym z nich jest „remake”, ujmowany przez Umberta Eco jako ponowne opowiedzenie historii, która cieszyła się już kiedyś powodzeniem7. Autor Wahadta Foucaulta wyodrębnia obok „remake’u” inne typy powtórzeń („retake”, „seria”, „saga”, „dialog intertekstualny"), zwracając uwagę na fakt, że były one wykorzystywane już we wcześniejszych epokach literackich. Według pisarza, remake nie jest nowym zjawiskiem na gruncie literatury: cata twórczość Szekspira to remake wcześniejszych fabut ${ }^{8}$. Marina Zagidullina uściśla czas pojawienia się remake'u na okres formowania się literatury narodowej danego kraju. Badaczka dodaje, że najbardziej oczekiwaną formą przeróbki było wykorzystanie znanego tematu poprzez ujęcie go w nowe, nacjonalne i bliskie określonemu społeczeństwu ramy9. Dodajmy jednak, że tego typu teksty literackie w XIX wieku traktowano jak pastisz, a więc najprostszy model imitacji wzorca ${ }^{10}$, po który sięgali twórcy niezbyt wysokich lotów. Korzenie remake’u sięgają zatem dwóch wieków wstecz, jednak współcześnie ten typ stylizacji zajmuje miejsce nie na peryferiach gatunków literackich, a w ich centrum. Zagidullina objaśnia znaczenie remake’u, określając go jako wyznacznik żywotności klasyki literackiej i jej zakorzenienia w świadomości narodowej. Gatunek remake’u byt, jest i będzie nie wyznacznikiem duchowej degradacji spoteczeństwa i symbolem utraty wyższych wartości, lecz obowiazkowym elementem kultury, mającym swoje specyficzne funkcje ${ }^{11}$. Jedną z nich jest objaśnianie dzieł klasyki i próba interpretacji „wiecznych tematów” w odniesieniu do aktualnych czasów. Podobnego zdania jest francuski pisarz Alain Robbe-Grillet, charakteryzujący remake jako swoista formę dialogu z klasyka, sposób opisania wspótczesności przy pomocy obrazów ze znanych klasycznych dziet literatury ${ }^{12}$.

Krytycy literaccy nie są zgodni w zasadniczej kwestii: jak należy interpretować zjawisko remake'u. Czy jest to wynik kryzysu literatury spowodowany brakiem możliwości zdefiniowania i opisania współczesności? Czy też przeciwnie, jest to ponowne

6 U. Eco, Innowacja i powtórzenie. Pomiędzy modernistyczna i postmodernistyczna estetyka, przeł. T Rutkowska, „Przekazy i Opinie” 1990, nr 1-2, s. 12-36.

Tamże, s. 18.

8 Tamże.

9 M. Zagidullina, Remejki, ili Ėkspansiâ klassiki, „Novoe Literaturnoe Obozrenie” 2004, nr 69, [online] http://magazines.russ.ru/nlo/2004/69/za13.html, 9 I 2017. Badaczka dodaje, że prototypami remake'ów są XVIII-wieczne poematy heroikomiczne, w których antyczni bohaterowie występują we współczesnych dla tego wieku sytuacjach i posługują się prostym językiem, np. Eneida Iwana Kotlarewskiego.

10 Zob. S. Balbus, Między stylami..., s. 22-24; R. Nycz, Parodia i pastisz. Z dziejów pojęć artystycznych wświadomości literackiej $X X$ wieku, [w:] tenże, Tekstowy świat. Poststrukturalizm a wiedza o literaturze, Warszawa 1993, s. 233-235.

$11 \quad$ M. Zagidullina, Remejki, ili... Wszystkie tłumaczenia tekstów obcojęzycznych, jeśli nie podano inaczej, moje, M.K.

12 Cyt. za: I. Gubin, Rimejk kak tendenciâ (slučaj Olega Bogaeva), [online] http://litbook.ru/article/ 4164/, 10 I 2017. 
odkrywanie tekstów klasycznych, próba opisu teraźniejszości za pomocą kodów wypracowanych przez tradycję literacką. Trwające spory świadczą o wyjątkowym zainteresowaniu tą formą adaptacji, mimo to jak dotąd nie powstała satysfakcjonująca definicja terminu „remake”. Dosłowne tłumaczenie z języka angielskiego oznacza przeróbkę, stworzenie na nowo, ponowne wykonanie. W słownikach (wyrazów obcych Władysława Kopalińskiego ${ }^{13}$ czy języka polskiego PWN ${ }^{14}$ ) hasło odnosi się jedynie do produkcji kinematograficznych i oznacza nową wersję istniejącego już filmu. W kontekście dzieł literackich definicja remake'u posiada znacznie bogatsze i bardziej skrupulatne wyjaśnienia w badaniach rosyjskich. W Słowniku Wyrazów Obcojęzycznych Leonida Krysina znajdujemy hasło: remake - nowsza wersja lub interpretacja wcześniej powstatego dzieta (sztuki, filmu, muzyki, literatury). Remake nie cytuje i nie parodiuje źródta, lecz wypetnia je nowa, aktualna treściq ${ }^{15}$. Jelena Tarazewicz wprowadza autorską definicję terminu: chwyt artystycznej dekonstrukcji klasycznych fabut znanych dziet literackich, $w$ których autorzy w nowy sposób ujmuja, odtwarzaja i rozwijaja je na poziomie gatunku, idei, problematyki oraz bohaterów ${ }^{16}$. Analizując współczesną rosyjską dramaturgię, badaczka opracowała pięć typów przeróbek tekstów klasyki: „remake-motyw”, oparty na znanym motywie, wnosi nową artystyczną interpretację; ,remake-sequel” jest kontynuacją fabuły dzieła klasycznego; „remake-kpina”, którego celem jest ośmieszenie problemów stawianych przez klasyków; „remake-kontaminacja”, łączący kilka tekstów klasycznych; oraz „remake-reprodukcja”, stanowiący adaptację klasycznego tekstu i uaktualnienie problematyki w nim zawartej. Podobny materiał badawczy posłużył Siergiejowi Smirnowowi do wyodrębnienia odmiennych typów remake’u, opartych na gatunkowości: detektyw, fantazja i tragedia ${ }^{17}$. Smirnow, podobnie jak kilku innych rosyjskich literaturoznawców, ujmuje remake jako cechę swoistą współczesnej rosyjskiej dramaturgii, widoczną szczególnie w twórczości Nikołaja Kolady i jego uczniów ${ }^{18}$.

Zjawiskiem remake'u w prozie lat 90. zajmuje się również Galina Nefagina. Badaczka klasyfikuje ten typ przeróbki jako tendencję charakterystyczną dla konceptualizmu. Zaznacza jednak, że rosyjski remake czerpie inspiracje z tekstów klasycznych, w odróżnieniu od amerykańskiego, nakierowanego na motywy znane z literatury masowej $^{19}$. Rosyjskie przeróbki znanych dzieł charakteryzują się wysokim stopniem oryginalności, co pozwala traktować je jako utwory samoistne, wnoszące nowe spojrzenie na znane socjalno-filozoficzne problemy. Klasyka pełni funkcję skarbnicy wartości

13 Remake, [w:] W. Kopaliński, Stownik wyrazów obcojezycznych i zwrotów obcojezycznych z almanachem, cz. 2, Warszawa 2007, s. 120.

Remake, [w:] Stownik jezzyka polskiego, [online] http://sjp.pwn.pl/szukaj/remake.html, 4 I 2017.

15 Rimejk, [w:] L. Krysin, Tolkovyj slovar' inostrannyh slov, Moskva 2007, s. 235.

16 E. Tarazevič, Rimejk v sovremennoj russkoj dramaturgii, [w:] Sovremennaâ russkaâ literatura. Problemy izučeniâ i prepodavaniâ. Materialy Meždunarodnoj naučno-praktičeskoj konferencii, Perm' 2006, s. 29.

17 C. Smirnov, Rimejk (parafraza) v „novojrusskoj” drame, [online] http://mion.isu.ru/filearchive/ mion_publcations/sbornik_Sib/6_2.html, 11 XI 2016.

18 Zob. A. Maroń, Remejk kak forma sozdaniâ avtorskogo mira v p’esah Nikolaâ Kolâdy (kvoprosu o puškinskom i gogolevs), „Slavia Orientalis” 2012, nr 2, s. 201-212.

19 G. Nefagina, Russkaâ proza konca HH veka, Moskva 2003, s. 227. 
moralnych, aktualnych we współczesnych czasach. $\mathrm{Z}$ tego względu zasadnicza funkcja remake'u opiera się na rozpoznawalności oryginału. Stopień obeznania z archetekstem umożliwia wniknięcie w problematykę remake'u. Dlatego im lepsza znajomość oryginału, tym większe możliwości właściwego odczytania jego współczesnej adaptacji. Nefagina wyróżnia dwa poziomy analizy remake’u: podstawowy i wtórny. Pierwszy z nich oznacza samodzielne odczytanie tekstu, bez odwołań do klasyki. Drugi poziom, określany jako „sedno” remake’u, zakłada zrozumienie związków z dziełem wcześniejszym, w czym jest zawarta głębia autorskiego zamysłu ${ }^{20}$.

Z kolei Andriej Urickij dzieli przeróbki tekstów klasycznych na pseudoremake i p-remake ${ }^{21}$. O ile pierwszy z terminów odnosi się do adaptacji, których zrozumienie nie wymaga sięgania do dzieła adaptowanego, o tyle drugie pojęcie oznacza przeróbkę, której nie sposób właściwie odczytać bez znajomości źródła. Autor dodaje: Dwoista jest natura remake'u - istnieje sam $z$ siebie i w nierozerwanej więzi z prototypem ${ }^{22}$.

Wobec powyższego zasadnym wydaje się postawić pytanie o różnice między intertekstualnością literatury a remakiem. Zagidullina uwypukla dążenie do namacalności tekstu klasycznego, charakterystyczne dla twórców remake'ów: manifestowana orientacja na konkretny obraz literacki, kalkulacja na rozpoznawalność bazowego tekstu (nie tylko elementu - aluzji, lecz oryginatu $w$ catości $)^{23}$. Remake zatem jest tworzony z myślą o czytelniku znającym tekst bazowy. Adaptowany utwór nie jest cytowany czy parodiowany, lecz napełniany nową, aktualną treścią. Jest to próba zachowania więzi z klasyką poprzez uaktualnienie problematyki pretekstu, uwspółcześnienie bohaterów i świata ich otaczającego.

Jednymi z częściej wykorzystywanych w remake’u tekstów klasycznych są dzieła Mikołaja Gogola. Niektóre z utworów doczekały się ogromnej liczby przeróbek, zarówno w ujęciu postmodernistycznym z charakterystycznym elementem dekonstrukcji, jak i w stylistyce realistycznej ${ }^{24}$. Zainteresowanie twórczością pisarza, znikome za jego życia, wzrosło w II połowie XIX wieku i przetrwało do czasów współczesnych. Wynika to z aktualności problemów postawionych przez autora Martwych dusz, ponadczasowych tematów, jak również aury tajemniczości, jaką owiana jest biografia pisarza. Każde kolejne pokolenie literackie próbuje odnaleźć nowy sens tekstów Gogola, odkryć ich przesłanie, zmierzyć się z zagadką jego dzieł. Co ważne, w pracach klasyka

20 Taż, Rimejk v sovremennoj russkoj proze, [w:] Vzaimodejstvie literatur v mirovomslavânskom processe, Grodno 1996, s. 193.

21 A. Urickij, Dubl' vtoroj, „Družba narodov” 2002, nr 3, [online] http://magazines.russ.ru/druzhba/ 2002/3/ur.html, 16 I 2017.

22 Tamże.

23 M. Zagidullina, Remejki, ili...

24 Zob. V. Kravčenko, Užin c klounom, „Znamâ” 1992, nr 6, s. 148-190; Novye peterburgskie povesti, red. P. Krusanov, Moskva 2006; A. Korolev, Golova Gogolâ, Moskva 2000; E. Dolgopât, Rol', [w:] taż, Garderobsìk, Moskva 2005, s. 151-168; L. Giršovič, „Vij”, vokal'nyj cikl Šuberta na slova Gogolâ, Moskva 2005; A. Melihov, Novosvetskie pomesìiki, „Znamâ” 2007, nr 7, [online] http://magazines.russ. ru/znamia/2007/7/me4.html, 15 I 2017; Â. Verov, Gospodin Čičikov, Moskva 2005; N. Sadur, Brat Cíčikov, Pannočka, [w:] taż, Obmorok, Vologda 1999, i inne. 
twórcy znajdują potwierdzenie aktualności „przeklętych problemów”, przed jakimi staje współczesny człowiek. Gogolowska tradycja jest żywa nie tylko w rosyjskiej literaturze, ale również w światowym dziedzictwie kulturowym ${ }^{25}$. Świadczy to o uniwersalnym wymiarze dzieł Gogola i ich przystawalności do wielu miejsc i czasów.

Jednym z tekstów Gogola cieszących się niesłabnącym zainteresowaniem jest $S z y$ ne ${ }^{26}$ (Шинемъ, 1842), wchodzący w cykl Opowieści petersburskich (Петербургские

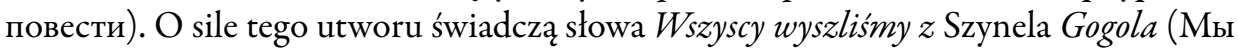
все вышии из Шинели Гоголя), których autorstwo przypisuje się Fiodorowi Dostojewskiemu ${ }^{27}$. Pozornie błaha historia petersburskiego radcy tytularnego Akakiusza Akakiuszowicza Kamaszkina ${ }^{28}$ stała się kodem, pozwalającym ukazać meandry życia w urzędniczej Rosji. Opowieść o „małym człowieku” („маленький человек”) jest często przywoływanym tematem remake'ów, potwierdzającym aktualność problematyki w kolejnych wiekach. Szynel prezentuje rozmiar biurokratyzacji i bezduszność systemu opartego na Tabeli rang. Jest to także zasadnicza tematyka utworu Czapka (Шапка, wyd. 1988 ${ }^{29}$, w którym w skali hiperbolicznej Władimir Wojnowicz ukazał walkę radzieckiego pisarza o literackie wyróżnienie. Historia Kamaszkina jest także próbą zwrócenia uwagi na przyziemne życie „małego człowieka”. Do tego motywu odwołują się Dmitrij Gorczew w opowiadaniu Telefon (Темефон, 2007) ${ }^{30}$ i Władimir Szynkariow w Mieszkaniu (Квартира, 2006) ${ }^{31}$. Oba teksty są współczesną wersją historii Gogolowskiego bohatera. Finał Szynelu z akcentem na zwrócenie godności Akakiuszowi stał się początkiem „remake'u-sequelu” Olega Bogajewa, zatytułowanego Baszmaczkin. Cud szynelu w jednym akcie ${ }^{32}$ (Башмачкин. Чудо шинели в оАном Аействии, 2002).

Zasadniczym celem tych remakeów jest ukazanie „nieśmiertelności” klasycznego tekstu. Twórcy, biorąc na literacki warsztat dzieło Gogola, próbują nawiązać dialog

25 Na mocy decyzji UNESCO rok 2009 ogłoszono „Rokiem Mikołaja Gogola”. Z tej okazji w wielu państwach odbyły się uroczystości poświęcone kulturowej spuściźnie pisarza.

26 M. Gogol, Szynel, przeł. J. Wyszomirski, [w:] tenże, Opowieści, oprac. B. Galster, przeł. J. Wyszomirski, J. Tuwim, J. Brzęczkowski, Wrocław 1972, s. 155-193. Badacze stoją na stanowisku, że inspiracją do napisania utworu był Żywot Akakiusza Synajskiego (Житие Акакия Синайского), z którym Go-

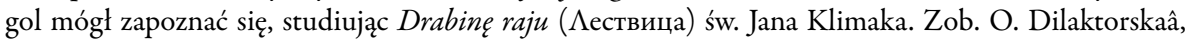
Fantastičeskoe v «Peterburgskih povestâh» N. Gogolâ, Vladivostok 1996; V. Markovič, Peterburgskie povesti N. Gogolâ, Leningrad 1986; D. Emec, Žitijnyetradicii v povesti Gogolâ «Šinel», http://www. proza.ru/2001/12/09-02, 10 IV 2017.

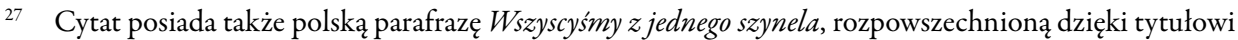
spektaklu Grupy Rafała Kmity, którego premiera odbyła się w 1997 roku.

28 Nazwisko bohatera Башмачкин podaję zgodnie z tłumaczeniem J. Wyszomirskiego - Kamaszkin. Zob. M. Gogol, Szynel...

29 W. Wojnowicz, Czapka, przel. E. Desperak, Warszawa 1990.

30 D. Gorčev, Telefon, [w:] tenże, Dikaâ žizn' Gondvany, [online] http://e-libra.ru/books/198560-dikaya-zhizn-gondvany.html, 12 I 2017.

31 V. Šinkarev, Kvartira, [w:] Novye peterburgskie povesti, red. P. Krusanov, Sankt Peterburg 2006, s. 161188.

32 O. Bogaev, Bašmačkin. Čudo šineli v odnom dejstvii, [w:] tenże, Russkaâ narodnaâ počta. 13 komedij, Ekaterinburg 2012, s. 365-424. 
z klasyką, dokonać reinterpretacji problemów i uaktualnić XIX-wieczną tematykę. Każdy z nich czyni to jednak w odmienny sposób, co może świadczyć zarówno o potencjale twórczym pisarzy, jak i szerokich możliwościach tej formy adaptacji.

Wojnowicz przeniósł historię opowieści z XIX-wiecznego Petersburga do XX-wiecznej Moskwy, ze środowiska urzędniczego do zamkniętego grona pisarzy radzieckich. Motto Tę czapkę uszytem z szynela Gogola. Autor (Эту шапку я сшим из шинели Гоголя. Автор), zamieszczone w pierwodruku opowiadania, zostało usunięte przez pisarza z wydania książkowego. Wojnowicz sądzit, że epigraf wprowadza element gry literackiej ${ }^{33}$. Zabieg ten może świadczyć o autorskiej rezygnacji z metatekstualnej sugestii. Mógł mieć na celu aktywizację czytelnika poprzez zmotywowanie odbiorcy do samodzielnych poszukiwań relacji mikropowieści z Gogolowskim Szynelem. Przypuszczalnie była to także próba wyeksponowania tematyki charakterystycznej dla okresu radzieckiego ${ }^{34}$. Jednak rezygnacja z bezpośredniego odniesienia do Szynelu nie wpłynęła w sposób znaczący na odbiór utworu w kategorii relacji z pretekstem Gogola. By wymienić związki najbardziej oczywiste, pojawiają się one już na poziomie cech gatunkowych obu utworów, organizacji fabuły, groteskowości, kreacji pierwszoplanowych bohaterów czy symboliki tytułowych przedmiotów.

$\mathrm{Z}$ drugiej strony, znajomość fabuły opowieści petersburskiej nie jest warunkiem koniecznym do zrozumienia utworu Wojnowicza. Potwierdza to tezę Nefaginy o dwupoziomowej budowie remake'u. Czapkę można odczytać z poziomu podstawowego, bez sięgania do pretekstu. Zwalnia to niejako czytelnika z możliwości wejścia w dia$\log$ z klasyką. Najistotniejszym tematem poruszanym przez rosyjskiego emigranta jest sytuacja twórcy w Związku Radzieckim oraz związane z nią pojęcia: cenzury ( $w$ tym również wewnętrznej), wolności twórczej, roli prawdy i estetycznych funkcji literatury, samizdatu i tamizdatu. Problematyka utworu oscyluje także wokół sfery obyczajowej okresu radzieckiego: instytucji małżeństwa, roli i miejsca rodziny w społeczeństwie, emancypacji kobiet (na przykładzie Kukuszy), konfliktu wewnątrzpokoleniowego (relacja Rachlina z synem). Tłem utworu jest sytuacja polityczna omawianych czasów: walka $\mathrm{z}$ kosmopolityzmem, kwestia postawy obywatelskiej, obowiązek donosu, inwigilacja mieszkańców ZSRR, kult władzy.

Wojnowicz wprowadza czytelnika do zamkniętej grupy „inżynierów dusz ludzkich” - urzędników od literatury. W utworze jest to skorumpowana i zbiurokratyzowana struktura, zdominowana przez funkcjonariuszy KGB. Miejsce pisarza, poruszającego dotąd ludzkie sumienia, gotowego na służbę w imię najwyższych wartości, zajęła potężna grupa „kaprali od literatury”35. Krystyna Pietrzycka-Bohosiewicz zauważa, że od pisarza radzieckiego żądano przede wszystkim, by wypowiadał się jednoznacznie i zajmował

33 A. Dudek, Wtadimira Wojnowicza odkrywanie zamystu, czyli „życie jakie jest”, [w:] Realiści i postmoderniści. Sylwetki wspótczesnych rosyjskich pisarzy emigracyjnych, red. L. Suchanek, Kraków 1997, s. 102.

34 Elżbieta Pańkowska określa świadomą nieprawomyślność Wojnowicza jako odtajnianie mechanizmów życia radzieckiego. E. Pańkowska, Twórczość Wtadimira Wojnowicza, Białystok 2009, s. 10-11.

35 L. Suchanek, Świadkowie, oskarżyciele, sprzymierzeńcy i obrońcy. O postawach pisarzy rosyjskich, [w:] Dać świadectwo prawdzie. Portrety wspótczesnych pisarzy rosyjskich, red. L. Suchanek, Kraków 1996. 
określoną przez partię postawę polityczną ${ }^{36}$. Swobodna myśl twórcza, wolność przekonań, własne upodobania artystyczne zostały unicestwione w oficjalnym kręgu, co doprowadziło do unifikacji i nacjonalizacji kultury. Rachlin, podobnie jak Kamaszkin, zajmuje ostatnią, najmniej znaczącą pozycję w kilkuwarstwowym układzie państwowym.

Elżbieta Pańkowska zaznacza, że Wojnowicz traktuje Rachlina jak soczewkę odbijająca to, czym wtadza radziecka byta dla zwyktych śmiertelników, którzy przywykli do specyficznej obyczajowości, obrzędowości sowieckiej ${ }^{37}$. Bohater Czapki jest jednocześnie typowym produktem systemu biurokratycznego, z charakterystyczną cechą osobowości: „myśleniem instytucjonalnym”, a więc stosującym w życiu „kancelaryjne” normy obyczajowe i wyznającym w pełni „kancelaryjny” pogląd na świat ${ }^{38}$. Rachlin nie myśli o ludziach w kategoriach innych niż zajmowana przez nich pozycja społeczna, liczba wydanych książek czy wreszcie status materialny. Andriej Amalrik określił radziecką mentalność mianem „psychologii urzędniczej”, rozszerzając ją na wszystkie grupy społeczne: ze względu na to, iz wszyscy pracujemy na panstwo, wszystkich nas cechuje psychologia urzędnika - pisarzy, będacych cztonkami Zwiazku Pisarzy, uczonych, pracowników instytutu państwowego, robotników i kotchoźników - wszystkich w takim samym stopniu jak urzędników w KGB czy MSW ${ }^{39}$.

Dla tej postawy charakterystyczna jest, znana z wcześniejszych wieków, cicha, posłuszna egzystencja w toku przykładnej służby na rzecz państwa, przyjmowanie zastanego stanu jako naturalnej kolei losu, poczucie zagubienia w zaklętych kręgach urzędniczych korytarzy. Myślenie instytucjonalne/psychologia urzędnicza ujawniają się w uniżonym stosunku bohatera $C z a p k i$ do wysoko postawionego członka nomenklatury - Karetnikowa. Wojnowicz kreuje satyryczną postać wybitnego pisarza radzieckiego, jakim w oczach członków Związku Pisarzy Radzieckich jest Wasilij Stiepanow, by następnie pokazać go w domowym zaciszu, w dresowych spodniach i rozciągniętej koszulce, haustami opróżniającego alkohol prosto z butelki. Karetnikow za swe wiernopoddaństwo płaci wyrzutami sumienia, zagłuszanymi solidnymi dawkami alkoholu. Swój stosunek do partii tłumaczy: kiedy mi wolno, nienawidze jej, kiedy trzeba, jestem jej żotnierzem ${ }^{40}$. To klasyczny przykład dwójmyślenia, a więc: publicznie demonstrowana przychylność wobec przyjętych w środowisku ideatów i norm, które moga nie odpowiadać wewnętrznym przekonaniom jednostki, a nawet występować jako sprzeczne z prezentowanym światem wartości $i^{41}$.

36 K. Pietrzycka-Bohosiewicz, Historia zapisana w cztowieku... Wybrane problemy wolnej literatury rosyjskiej, Kraków 2008, s. 8.

37 E. Pańkowska, Twórczość..., s. 170.

38 Termin autorstwa Bohdana Galstera zaczerpnięty ze Wstępu do Opowieści Mikołaja Gogola. „Myśleniem instytucjonalnym” charakteryzuje się Popryszczyn - bohater utworu Pamiętnik szaleńca M. Gogola. B. Galster, Wstęp, [w:] M. Gogol, Opowieści..., s. CI.

39 A. Amal'rik, Prosusestvuetli Sovetskij Soûz do 1984?, [online] http://www.vehi.net/politika/amalrik. html, 12 I 2017.

40 W. Wojnowicz, Czapka..., s. 85.

41 A. Hlopin, Fenomen dvoemysliâ. Zapad i Rossiâ (osobennosti rolevogo povedeniâ), [online] http:// ecsocman.hse.ru/data/157/463/1217/005Hlopin.pdf, 12 I 2017. 
Analiza utworu Wojnowicza z poziomu podstawowego pozwala na wniknięcie w świat ludzi pióra, skupionych w Moskiewskim Oddziale Związku Pisarzy Radzieckich. Przynależność do tego świata należy traktować jako zaszczyt, za który jednak płaci się wysoką cenę. Obok licznych usług (restauracje, kawiarnie, kino, fryzjer) pisarze mają także możliwość zdobycia wielu nieosiągalnych przez resztę społeczeństwa dóbr: materiałów potrzebnych do pracy twórczej, fachowo skrojonych garniturów, protez zębów, a także importowanych kranów do łazienki. Oferowane usługi i gratyfikacje w postaci trudno dostępnych produktów stały się bodźcem, zmuszającym twórców do zajęcia pozycji niemego świadka, posłusznie wykonujących polecenia organizacji.

Znacznie ciekawsza interpretacja rzeczywistości radzieckiej zaprezentowanej w książce Wojnowicza odbywa się z poziomu wtórnego, a więc za pośrednictwem i ze znajomością tekstu Szynelu. Ironicznie przedstawiona „klasa służebna”, jaką uczyniono z radzieckich artystów, może być rozpatrywana przez pryzmat krytykowanej przez Gogola Tabeli rang. System służby państwowej, wprowadzony przez Piotra I, doprowadził do rozrostu biurokracji i kultu rangi. Rosyjskiemu społeczeństwu obraz urzędnika zaczął kojarzyć się z lapownikiem i formalistą ${ }^{42}$. Pogarda dla urzędników niższych rang, mierne płace i przemożna chęć uzyskania awansu zrodziły wymarzony świat dla amatorów łapówek i karierowiczów. Było to przyczyną rozrostu korupcji i biurokracji, nieodłącznej części systemu administracyjnego w Imperium Rosyjskim i Związku Radzieckim. Nowoczesne środki komunikacji i łączności zapewniły stały nadzór centrali nad najbardziej oddalonymi guberniami. Uprzywilejowana klasa urzędników ogarnęła wszystkie resorty, instytucje wewnętrzne i zagraniczne, tworząc klasę panujących.

$\mathrm{Na}$ absurdalność systemu biurokratycznego w carskiej i radzieckiej Rosji wskazuje liczba gabinetów, przez które musieli przejść bohaterowie obu historii. Końcem tej wędrówki jest poczucie bezsilności i upokorzenia. $Z$ machiną państwową nie sposób wygrać, zwłaszcza z pozycji niewiele znaczącego trybiku. Kamaszkin i Rachlin są niewolnikami systemu, dla których próba odzyskania godności jest pasmem porażek. Ukazuje to małość człowieka w zdehumanizowanym państwie, jego nikłą rolę i brak znaczenia. Analiza Czapki jako remake’u opowieści Szynel pozwala wysnuć wniosek, że zniewolenie jednostek charakterystyczne dla okresu radzieckiego, myślenie instytucjonalne, uległość i wszechobowiązujący strach mają swoje korzenie w systemie carskim.

Związki utworu Wojnowicza z opowieścią Gogola ujawniają się już na poziomie tytułów. Zarówno szynel, jak i czapka są częściami garderoby, bez znajomości fabuły jawią się jako słowa uczuciowo obojętne. Szynel nabiera głębszego znaczenia, jeśli skoncentrujemy się na wyjaśnieniu terminu, dokonanym przez tłumacza tekstu - Jerzego Wyszomirskiego: szynel to duch koszarowy caryzmu, hierarchia rang i godności, biurokratyzm, strychulec, przedmiot nienawiści jednych i marzenia innych ${ }^{43}$. Szynel okazuje się więc słowem kluczem, potęgującym ruch wyobraźni w kierunku dalszych skojarzeń. Ten urzędniczy płaszcz w zestawieniu z postacią głównego bohatera ma podwójne

42 Zob. J. Łotman, Ludzie i stopnie, [w:] tenże, Rosja i znaki. Kultura szlachecka w wieku XVIII i na początku XIX, przeł. B. Żyłko, Gdańsk 2009, s. 21-50.

43 J. Wyszomirski, przyp. 1 w tekście właściwym: M. Gogol, Szynel..., s. 156. 
znaczenie: $\mathrm{z}$ jednej strony to pozornie błahe marzenie o ciepłym zimowym palcie, z drugiej - jest symbolem utraconej godności, próbą odnalezienia wartości uniwersalnych w czasach, w których dokonano ich degradacji. Opierając się na rozważaniach Henryka Elzenberga, o wartości danego przedmiotu możemy mówić w dwóch znaczeniach: jako o przedmiocie „wartościowym”, odpowiadającym czyimś pragnieniom, potrzebom, tendencjom, aspiracjom, zdolnościom (wartość utylitarna, elektywna); bądź też jako o przedmiocie posiadającym „wartość perfekcyjną”, niepodlegającą sądom, bezwzględną ${ }^{44}$. Wartości perfekcyjne stoją zdecydowanie wyżej w aksjologicznej drabinie wartości, bowiem konstytuują ludzkie postępowanie, które podlega w całości normom wynikającym stąd, że wartości perfekcyjne istnieją i obowiązują ${ }^{45}$. W tym znaczeniu szynel wpisuje się w krąg przedmiotów o wartości utylitarnej, zaspokajającej pragnienia konkretnego człowieka, choć niestanowiącej przedmiotu marzeń ogółu. Jednak wnikając w warstwę symboliczną utworu, tytułowy szynel staje się wartością perfekcyjną - godnością, o której urzeczywistnienie Kamaszkin postanawia walczyć. Elzenberg, charakteryzując wartość perfekcyjną, podkreśla: jeżeli znajdzie się sprawca świadomy, zdolny ja [wartość perfekcyjną] urzeczywistnić faktycznie, to dla tego sprawcy (przy uwzględnieniu różnorodnych, komplikujących sprawę, realnych czynników sytuacyjnych) powstaje konkretny, w czasie i miejscu, obowiazek, by powinny stan rzeczy urzeczywistnić faktycznie ${ }^{46}$.

Przed podobnym wyzwaniem stanął bohater utworu Wojnowicza. Utylitarna wartość przedmiotu zyskuje w toku fabuły wartość perfekcyjną. Czapka jako nakrycie głowy jest znakiem uczuciowo neutralnym. Początkowo nawet jako taka jawi się głównemu bohaterowi, który posiada już elegancką i ciepłą czapkę z wilka, mającą dla niego wartość sentymentalną. Sam autor również bawi się tym słowem, nadając mu wiele znaczeń. Pierwsze skojarzenie Rachlina na wieść o wręczaniu czapek to: pisarzom dali po $c z a p c e^{47}$ (mowa o autorach listu otwartego, którzy w mniemaniu bohatera otrzymali dożywocie, czyli „czapę”); kolejna myśl to:pisarzom szyja sprawę, czyli mają zamiar ich posadzicín. Z $\mathrm{Z}$ właściwą dla swej maniery twórczej groteską Wojnowicz wskazuje na wieloznaczność pojęcia. Wprowadza także czytelnika w atmosferę inwigilacji i strachu charakterystyczną dla radzieckiej rzeczywistości, w której bohaterowie posługują się sobie tylko znanym szyfrem. W czasach radzieckich uczucie to stało się czynnikiem stymulującym postępowanie obywateli. Był to jednocześnie środek i narzędzie pozwalające na „obróbkę” duszy ludzkiej. Nie dziwią więc mylne wyobrażenia Rachlina o zorganizowanej akcji przydzielania czapek, jeśli pod uwagę weźmiemy czasy, w których zamiast mówić otwarcie, ludzie w obawie przed karą - szeptali. Tytułowa czapka nabiera jednak głębszego sensu, kiedy dowiadujemy się o faktycznym znaczeniu reglamentowanych nakryć głowy: zgodnie z zarządzeniem kierownictwa Funduszu Literatury

\footnotetext{
44 H. Elzenberg, Wartość i cztowiek. Rozprawy z humanistyki i filozofii, Toruń 2005, s. 15-19.

45 Tamże, s. 18.

46 Tamże.

47 W. Wojnowicz, Czapka..., s. 30.

48 Tamże, s. 31.
} 
pisarzom będa szyć czapki odpowiednie do ich rangi. Dla wybitnych z mtodego rena, dla stawnych z pizmaka, a dla znanych ze świstaka ${ }^{49}$. Właściwa akcja utworu rozpoczyna się w tym miejscu, bowiem czapka, podobnie jak szynel, stanowi o wartości jednostki, pozycji w zhierarchizowanym świecie. Pozornie błahe części odzieży zyskują magiczną moc, decydują o dalszej egzystencji, rozstrzygają odwieczne zagadnienie „być czy mieć”. Jednak w świetle rozpatrywanych utworów funkcja „mieć” stanowi podstawę dla funkcji „być”. Nie jest to czysty konsumpcjonizm, zgodnie z którym chęć posiadania pewnych przedmiotów ma pierwszeństwo nad sferą duchową. Rozróżniając ludzkie potrzeby na prawdziwe (niezbędne do życia) i fałszywe (przedmioty zbytku), czapki nie można zaliczyć do minimum niezbędnego do przeżycia. Dla bohaterów tytułowe przedmioty stanowią odbicie własnej duszy, rozpoznają oni samych siebie w upragnionych rzeczach. Pożądanie płaszcza i czapki staje się drogą ku własnej osobie, odnalezieniem swego miejsca w społeczeństwie, znakiem informującym o istnieniu i nadającym mu sens. Są one także czynnikiem zmuszającym bohaterów do działania w celu urzeczywistnienia wartości perfekcyjnej. Dzięki nim z postaci biernych, owładniętych marazmem, pogodzonych ze swoim życiem przeistaczają się w bohaterów czynu.

W Czapce (podobnie jak w Szynelu) „batalia” o godność kończy się śmiercią bohaterów, co zdaniem Pańkowskiej sytuuje Rachlina w gronie „małych ludzi”, walczacych i ginacych $w$ starciu $z$ bezdusznym systemem ${ }^{50}$. I choć final obu historii jest podobny, Wojnowicz w odmienny sposób charakteryzuje swojego bohatera. Podczas gdy Kamaszkin doskonale zdawał sobie sprawę ze swojej niskiej pozycji społecznej, Rachlin w głębi ducha wierzył w swój talent, był nawet przekonany o pożytku, jaki płynie z jego utworów, opiewających czyny „dobrych ludzi”. Pewność tę zawdzięczał pochlebnym recenzjom swoich dzieł, sztukom teatralnym i scenariuszom filmowym powstałym na motywach jego utworów, wreszcie jedenastu wydanym pozycjom książkowym bez zastrzeżeń ze strony cenzury. W tej sytuacji przyznanie mu czapki z futra lepszego gatunku wydaje się kwestią bezsporną. Jednak pominięcie jego osoby w trakcie wręczania czapek odsłania przed bohaterem faktyczną pozycję, jaką zajmował w oczach władzy: dla nas to za mato, że nie jesteś przeciw. Powinieneś być za. Będziesz walczyt o pokój, będziesz pisat o sekretarzach rajkomów, obkomów, wtedy wszystko dostaniesz. Wybaczymy ci, żeś Żyd, dacze ci damy i czapkę $e^{51}$. Ostatecznie propozycja uhonorowania Rachlina czapką z kota średnio puszystego unaocznia mu niskie miejsce w hierarchii pisarzy radzieckich, a co za tym idzie, określa jego pozycję w życiu.

Andrzej Dudek zwraca uwagę na to, że irracjonalna, zakończona obtędem, walka Rachlina o prawo do czapki urasta do rangi protestu matego cztowieka, broniacego wtasnej tożsamości przed urzeczawiająca machina biurokratycznego systemu $u^{52}$. Jak widać, Wojnowicz wykorzystuje motyw z opowiadania Szynel, jednak swego bohatera obdarza wyjątkową siłą charakteru, pomocną w walce z systemem. Świadczyć o tym mogą

\section{Tamże.}

50 E. Pańkowska, Twórczośćc.., s. 172.

51 W. Wojnowicz, Czapka..., s. 88.

52 A. Dudek, Wtadimira Wojnowicza odkrywanie zamystu..., s. 104. 
słowa Rachlina: będę walczyt, drapat, gryzt, ale obrażać mojej godności ludzkiej nie po$z w o l e^{53}$, które wskazują na determinację bohatera i uparte dążenie do obranego celu. Zmiana machiny państwowej na despotyczny ustrój komunistyczny dotyczy również wewnętrznego świata „małego człowieka”. Nowe, równie nieludzkie czasy nakazują walczyć o sprawiedliwość w bardziej odważny sposób aniżeli poetycka pośmiertna eskapada Kamaszkina. Widać więc, iż Wojnowicz poprzez gogolowską fabułę ukazuje funkcjonowanie człowieka, doceniającego swoją godność w państwie, w którym jednostka jest niczym, a system - wszystkim ${ }^{54}$.

Remakiem Szynelu jest także opowiadanie Dmitrija Gorczewa (1963-2010) Telefon. Przedwcześnie zmarły pisarz i ilustrator jest autorem kilkudziesięciu opowiadań, szkiców i miniatur, w których kontynuuje literackie tradycje Michaiła Zoszczenki i Daniiła Charmsa. Popularność zdobył za pośrednictwem bloga, na którym regularnie publikowal swoje utwory. Pisarza doceniono za wyjątkowe poczucie humoru, lekki język $\mathrm{i}$ „życiową” tematykę. W swoich tekstach przedstawiał współczesny świat absurdu, pozornie pozbawiony wyższych wartości, pełen banalności i idiotyzmów dnia codziennego $^{55}$. Swoistą cechą twórczości Gorczewa jest próba opisu życia pospolitego człowieka, znanego z rosyjskiej klasyki jako „mały człowiek”. Prowadzi to do deheroizacji fabuły, bowiem bohaterowie krótkich form nie pragną stać się lepszymi, nie myślą o zmianie swojego położenia. Jeśli zaś taka myśl się pojawi, zostaje stłamszona przez otoczenie i rzeczywistość, w których przyszło żyć współczesnym „uniżonym”.

„Małym człowiekiem” w opowiadaniu Telefon jest Aleksiej Aleksiejewicz, pracownik petersburskiej firmy wydawniczej. Bohater to skromnie żyjący samotny mężczyzna bez reszty oddany swojej pracy. W ślad za tekstem Gogola swoje zajęcie zarobkowe traktuje jak „służbę": wieczorami, przychodząc ze stużby, uprzejmie kłaniał się sąsiadom, gotowat parówki lub pielmieni i pit herbatę ${ }^{56}$. Podobnie do Kamaszkina, Aleksiej zajmuje jedno z niższych stanowisk. Jest tak samo cichy, skupiony na pracy i dokładny w przepisywaniu zleconych tekstów. Radość egzystencji Aleksieja opiera się na poczuciu dobrze spełnionego obowiązku służbowego. Praca wypełnia całe jego życie, które toczy się według schematów, zapewniających bohaterowi poczucie stabilności i bezpieczeństwa.

W oczach pozostałych pracowników bohater jest sympatycznym odludkiem: Mtodzi pracownicy instytucji lubili Aleksieja Aleksiejewicza z całego serca, jednak na swój sposób i dlatego czasami żartowali z niego ${ }^{57}$. Żarty te można określić w kategorii młodzieńczych wybryków: pod nieobecność starszego kolegi dopisywali litery do gotowych już tekstów, stawiali dodatkowe kropki lub przecinki. Zawsze jednak przepraszali Aleksieja, który niezwłocznie przystępował do nanoszenia poprawek. Ceniono jego zaangażowanie w pracę, a jednocześnie nie widziano w nim zagrożenia dla własnej kariery.

\footnotetext{
53 W. Wojnowicz, Czapka..., s. 94.

54 A. Amal'rik, Zapiski dissidenta, Moskva 1991, s. 8.

55 K. Ŝerbino, V. Polâkovskij, Recenziâ na knigu: Gorčev D. „Dikaâžzizn’ Gondvany”, „Novoe Literaturnoe Obozrenie" 2009, nr 95, [online] http://magazines.russ.ru/nlo/2009/95/po20.html, 22 I 2017.

56 D. Gorčev, Telefon...

57 Tamże.
} 
Rozszerzając typologię remake'ów zaproponowaną przez Tarazewicz na utwory prozatorskie, ten typ remake'u określimy jako reprodukcję, a więc adaptację klasycznego tekstu i uaktualnienie problematyki w nim zawartej. Gogolowski obraz „małego człowieka” i jego przyziemnych marzeń zostaje uwspółcześniony za sprawą tytułowego telefonu, którego chęć posiadania staje się źródłem przemiany głównego bohatera. Aleksiej, zgodnie z firmowymi wytycznymi dotyczącymi obowiązku posiadania telefonu komórkowego, zaopatrzył się w najprostszy i najtańszy model dostępny w komisie. Pewnego dnia staromodny telefon stał się obiektem kpin jednego z młodych pracowników: Mój Boże! Poznaję ten aparat! Aleksieju Aleksiejewiczu, nawet Pan nie wie, co nosi $w$ swojej torbie! Tym samym telefonem Iwan Groźny zabit swojego syna! $Z$ tego telefonu Piotr dowodzit Bitwa Pottawska! A Pan pewnie jeździ z nim w metrze bez ochrony. Należy go zanieść do Ermitażu! $!^{58}$.

Ta sytuacja doprowadziła Aleksieja do płaczu, zwiastującego wewnętrzną przemianę. Od tego dnia praca przestała go cieszyć, pojawiła się nawet ulotna myśl o urlopie, z którego bohater bał się jednak skorzystać w obawie przed utratą pracy. Mężczyzna zaczął gromadzić pieniądze na najnowszy na rynku model telefonu komórkowego. Zakup poprzedziła lektura czasopism tematycznych z zakresu telefonii komórkowej, której bohater poświęcał każdą wolną chwilę.

Jak widać, w centrum uwagi Gorczewa znalazł się symbol obecnych czasów. Posiadanie telefonu komórkowego jest współcześnie traktowane jako warunek konieczny do życia. W dobie konsumpcjonizmu nowinki technologiczne stały się sygnifikacją prestiżu, statusu, a także komunikatem celów, wartościowań i umiejętności. Aleksiej, dotąd stroniący od technologii (w swojej pracy nie używał komputera, mimo iż stał na jego biurku; nie włączał telewizora ustawionego w rogu pokoju), uległ tej tendencji. Ascetyczne życie bohatera zostało napełnione nową treścią, zdominowaną chęcią podwyższenia swojego statusu w gronie pracowników wydawnictwa. Postanowit kupić sobie taki telefon komórkowy, aby wszyscy mtodzi żartownisie przygryźli język i nigdy więcej nie odważyli się tak z nim rozmawiac ${ }^{99}$. Niewinny żart kolegów z pracy uświadomił Aleksiejowi, że znajduje się on na marginesie wspólnoty, którą tworzą pracownicy instytucji. Zakup telefonu nie tylko pozwoli mu zintegrować się z otoczeniem, ale również umożliwi zaznaczyć swoją pozycję we współczesnym świecie. Odwołuje nas to do pojęć z zakresu antropologii rzeczy ${ }^{60}$. Marek Krajewski zauważa, że jednostka może stać się pełnoprawnym członkiem wspólnoty, o ile nauczy się od jej przedstawicieli posługiwania się obiektami tworzącymi jej kulturę materialną ${ }^{6}$. $Z$ tego względu bohater opowiadania Gorczewa, zanim zaopatrzył się w nowy telefon, dokonał wnikliwej analizy aktualnych trendów w telefonii komórkowej, poznał funkcjonalność aparatów telefonicznych i ich

\section{Tamże.}

59 Tamże.

60 Antropologia rzeczy (przedmiotów) - dział antropologii zajmujący się związkiem człowieka i rzeczy. Zob. J. Barański, Świat rzeczy. Zarys antropologiczny, Kraków 2007; T. Rakowski, Antropologia rzeczy. Wprowadzenie, „Kultura Współczesna” 2008, nr 3, s. 5-8.

61 M. Krajewski, Przedmiot, który ucztowiecza..., „Kultura Współczesna” 2008, nr 3, s. 49. 
szerokie możliwości zastosowania. Najnowszy model telefonu stał się odbiciem prawomocności członkostwa Aleksieja we wspólnocie. Aktem potwierdzającym włączenie do kolektywu było zaproszenie bohatera do pubu w celu uczczenia zakupu i przeproszenia pokrzywdzonego za niewybredny żart.

Związek pomiędzy przedmiotami a ludźmi urzeczywistnia się na wszystkich poziomach człowieczeństwa: gatunkowym, cywilizacyjnym, społecznym i indywidualnym ${ }^{62}$. Obok funkcji uspołeczniającej, nowy telefon odgrywa także rolę uczłowieczającą. W wyniku zakupu nowego aparatu bohater zaznaczył swoją indywidualność. Przedmioty, materializując preferowany w określonej spoteczności wzór opozycji pomiędzy tym, co jednostkowe, a tym, co spoteczne, czynia go obiektywnym i trwatym. Tym samym sq najbardziej czytelna, namacalna i naoczna odpowiedzia na pytanie o to, kim jestem ja ${ }^{63}$.

Zakup nowego telefonu przez bohatera wpłynął na zmianę jego postrzegania samego siebie. Aleksiej po raz pierwszy w życiu zaczął kreślić plany na przyszłość, włączając w nie niedostrzeganą wcześniej koleżankę z pracy. Jego myśli koncentrowały się także na wczasach w Turcji, mimo iż do tej pory urlop traktował jako zagrożenie utratą pracy. Zmienił się nastrój bohatera. Stał się on radosny, otwarty na kontakty z ludźmi, chętny do wspólnego świętowania. Świadczy to o wyjątkowej relacji opozycji ludzie przedmioty. Z jednej strony, człowiek tworzy przedmioty i nadaje im moc istnienia. Jest także odwrotna, bardziej skomplikowana strona tego związku: przedmioty mogą także tworzyć człowieka, dookreślać ludzkie istnienie. Wpływają na samoidentyfikację i wyznaczają poczucie własnej niepowtarzalności. Krajewski pisze na ten temat: Tym, co pomaga nam doświadczyć wtasnej odrębności, jest więc nie tyle rzecz, która pozostaje w moim posiadaniu i która nikt inny nie dysponuje, lecz przede wszystkim unikalność zwiazku, który mnie z nią tączy. Tylko dlatego każda z milionów osób noszacych dżinsy może czuć się niepowtarzalna, a każdy z posiadaczy iPoda wyjątkowy ${ }^{64}$.

Remake Gorczewa opiera się na tożsamym jak w Szynelu związku człowieka z pożądanym przedmiotem, który wypełnia monotonne życie nową treścią. Uwspółcześniony został jedynie ów przedmiot, kierując czytelnika w stronę materializacji kultury i konsumpcjonizmu.

Podobny jest także finał obu historii. Aleksiej po suto zakrapianym świętowaniu kupna aparatu telefonicznego stał się ofiarą kradzieży. Odmienne są jednak okoliczności utraty posiadanego przedmiotu. Napastnikami są funkcjonariusze milicji, co wskazuje na kolejną aktualizację klasycznej treści. Gorczew zwraca w ten sposób uwagę na bezprawie panujące w rosyjskich kręgach służb mundurowych. Badania przeprowadzone w 2002 roku przez CEORG (Central European Opinion Research Group) wśród mieszkańców sześciu państw (Rosja, Węgry, Polska, Bułgaria, Czechy, Litwa) dowodzą, że Rosjanie byli najmniej usatysfakcjonowani działalnością milicji. 66\% ankietowanych wyraziło negatywny stosunek do pracy funkcjonariuszy służb mundurowych. W związku z powyższym Rosjanie nie czuli się bezpiecznie w miejscu swojego zamieszkania,

\footnotetext{
62 Tamże, s. 44.

63 Tamże, s. 51.

64 Tamże, s. 51-52.
} 
co przyznało ponad 62\% ankietowanych ${ }^{65}$. Cykl reform w Ministerstwie Spraw Wewnętrznych FR przeprowadzonych w latach 2009-2011 miał na celu zmianę zakorzenionego w społeczeństwie negatywnego wizerunku milicji, kojarzonego z korupcją, brutalnością i nieudolnością ${ }^{66}$. Jedną z konsekwencji zmian było przemianowanie nazwy organów spraw wewnętrznych na Policję w 2011 roku $^{67}$. Jednak ankieta przeprowadzona przez Centrum Lewady po zakończeniu reform dowodzi, że 60\% ankietowanych Rosjan nie pokłada żadnych nadziei w przyjętych zmianach, a cały projekt jest jedynie dekoracyjną fasadą dla dalszego bezprawnego funkcjonowania służ $b^{68}$. Ma to wpływ na brak zaufania do instytucji policji, obawę o niesprawiedliwe potraktowanie i brak wiary w skuteczność jej działan ${ }^{69}$. Fabuła Szynelu stała się swoistym papierkiem lakmusowym współczesności. Absurd sytuacji, w jakiej znalazł się Aleksiej, polegał na fakcie, że jedyną instytucją, do której mógł zwrócić się poszkodowany, był najbliższy posterunek milicji, na którym rozpoznał swojego oprawcę. Rozpaczliwa sytuacja bohatera doprowadziła go do choroby alkoholowej, będącej przyczyną jego śmierci.

O związku fabuły Telefonu z Szynelem przypomina narrator w końcu opowiadania: No, no - powie dawno wszystko juz rozumiejący czytelnik. - Oczywiśsie, po śmierci Aleksiej Aleksiejewicz stat się zjawa i zacząt krążý po Petersburgu w poszukiwaniach swojego telefonu. Czy autor może sprzeciwić się takiemu czytelnikowi? Nie może. Gdyby autor byt bardziej pomystowy, z pewnościa wymyślitby jakiśnieoczekiwany i fantastyczny koniec. Niestety, nasze życie jest, $z$ matymi wyjatkami, monotonne i przewidywalne $e^{70}$.

Ostatecznie Gorczew, podobnie jak Gogol, uczynił pożytek z gtupiej śmierci ${ }^{71}$ bohatera, dodając, że w krótkim czasie w szeregach petersburskiej milicji doszło do oczekiwanych zmian wymierzonych $\mathrm{w}$ walkę $\mathrm{z}$ bezprawiem funkcjonariuszy: $o d$ tego czasu petersburska milicja nigdy nie zabiera wypitym przechodniom telefonów komórkowych $^{72}$.

We współczesnych realiach osadzona jest także fabuła remake’u Mieszkanie autorstwa współzałożyciela leningradzkiej grupy „Mitki” („Митьки”) $)^{73}-$ Władimira

65 Problema bezopasnosti, kačestvo raboty policii (milicii) i otnošenie $k$ smertnoj kazni v Bolgarii, Čehii, Bengrii, Litve, Pol'se i Rossii, [online] http://www.levada.ru/2002/08/04/problema-bezopasnostikachestvo-raboty-politsii-militsii-i-otnoshenie-k-smertnoj-kazni-v-bolgarii-chehii-vengrii-litvepolshe-i-rossii, 22 I 2017.

66 Federal'nyj zakon ot 7 fevralâ 2011 g. N 3-FZ „O policii”, „Rossijskaâ gazeta. Federal'nyj vypusk” 2011, nr 5401 (25), [online] https://rg.ru/2011/02/07/police-dok.html, 15 I 2017.

67 W. Radziwinowicz, Pan Policjant, „Gazeta Wyborcza” 2011, 11 II, [online] http://wyborcza.pl/ 1,76842,9086812,Pan_Policjant.html, 15 I 2017.

68 O reforme milicii, [online] http://www.levada.ru/2011/02/23/o-reforme-militsii, 15 I 2017.

69 Indeks doveriâ policii, [online] http://www.levada.ru/2013/03/04/indeks-doveriya-politsii, 15 I 2017.

70 D. Gorčev, Telefon...

71 Tamze.

72 Tamże.

73 „Mitki” - nieformalna grupa artystów i subkultura powstała w połowie lat 80. w Leningradzie z inicjatywy Dmitrija Szagina i Władimira Szynkariowa. Główne idee ruchu oraz nazwę (od imienia Szagina) sformułował Szynkariow w utworze Mitki (Митьки, 1984), wydanym w samizdacie i uznanym za 
Szynkariowa. Utwór przedstawia historię pisarza Wasilija Kazakowa, który swą życiową energię i wszystkie oszczędności przeznaczył na zakup wymarzonego lokum. Bohatera obserwujemy w przededniu planowanego odbioru dokumentów potwierdzających własność. Jego wątpliwości i narastający strach potęguje fakt kupna mieszkania bez pośredników, na tzw. czarnym rynku. Niejednoznaczną sytuację uświadamia Kazakowowi zaprzyjaźniona agentka nieruchomości: obecnie wysokiej jakości kolorowe ksero jest dostępne dla każdego. Dokumenty można powielić dziesięć razy i dziesięć razy można sprzedać jedno mieszkani $e^{74}$. Bohatera przeraża nie tylko możliwość utraty długo oszczędzanych pieniędzy, ale również zaprzepaszczenie szansy na lepsze życie w nowym miejscu. Egzystencja Wasilija diametralnie zmieniła się po rozwodzie, kiedy zamieszkał w komunałce, o czym mówi: nieprzerwany ból i wieczna tęsknota ${ }^{75}$. Wówczas cel swojego życia nakierował na przeprowadzkę, upatrując główną przyczynę marazmu i niechęci do świata w przeludnionym mieszkaniu komunalnym. Apatia odbiła się także na zaniku chęci do pracy literackiej, braku inicjatywy i zamysłu twórczego. Kazakow skoncentrował całą energię na gromadzeniu pieniędzy, by ostatecznie uwolnić się od znienawidzonego miejsca. Paradoksalność sytuacji ukazuje mu nowo poznany pisarz: cztery lata czekać, żeby zaczać żyć. Pan jest pisarzem, w rzeczy samej, pan sam dla siebie jest punktem oporu. Żeby żyć - sasiedzi nie sa przeszkoda, nawet najdziwniejsi ${ }^{76}$. Wiara Wasilija w to, że wraz ze zmianą mieszkania odmieni się jego życie, przypomina Gogolowskiego Akakiusza, dla którego sama myśl o nowym szynelu wypełniała życie bogatszą treścią. Otwarte zakończenie opowiadania Szynkariowa nie daje jednoznacznej odpowiedzi na pytanie, czy bohater otrzyma dokumenty poświadczające własność mieszkania. Jednak, jeśli uznamy utwór za remake Szynelu, niedopisany tragiczny finał historii staje się oczywisty. Poprzedzają go pesymistyczne myśli Kazakowa: nie ma we mnie nawet odrobiny wiary w to, że będę mieszkać w tym mieszkaniu. Obce, nieswoje mieszkanie. [...] Dlaczego nie poszedtem do biura nieruchomości, dlaczego nie zwrócitem się do znajomej agentki? [...] Każdy wpada w putapkę wtasnych pragnień. To, co dla kogoś jest najważniejsze - staje się przyczyna jego śmierci ${ }^{77}$.

Bezpośrednim odniesieniem do Gogolowskiego tekstu jest również refleksja o aurze Petersburga, którą żywią się jego mieszkańcy. Zbliżającą się tragedię bohatera zwiastują

manifest grupy. Ruch skupiał artystów malarzy, poetów, pisarzy i muzyków, niewpisujących się w nurt oficjalny. Uczestnicy grupy nie prezentowali spójnej idei twórczej. Łączyły ich otwartość, nonkonformizm, akceptacja wszelkiej odmienności, umiejętność współczucia, negacja dóbr materialnych, sprzeciw wobec systemu oraz zamiłowanie do alkoholu. Jednymi z najczęściej odwzorowywanych postaci w twórczości członków grupy byli marynarze i czerwonoarmiści. Dużą popularność „Mitki” zyskali po upadku ZSRR: ich obrazy zdobyły uznanie na arenie międzynarodowej, utwory były drukowane w wysokich nakładach. $Z$ upływem lat ruch utracił swą pierwotną formę. W 2008 roku w wyniku rozbieżności ideologicznych grupę opuścił Szynkariow. Zob. Mit’ki, [online] http://mitki.kulichki.net/, 31 I 2017; Mit'ki, [online] http://alternative_culture.academic.ru/69, 31 I 2017; A. Karpov, Novye Mit'ki, [online] http://karpov.hole.ru/texts/mitkil.htm, 31 I 2017.

74 V. Šinkarev, Kvartira..., s. 185.

75 Tamże, s. 163.

76 Tamże, s. 178.

77 Tamże, s. 182-183. 
współczesne niespokojne duchy, spotkane podczas nocnego spaceru: bandyci, milicjanci, alkoholicy, dziewczyny w ciasnych kioskach czytające tanie romanse ${ }^{78}$.

Uaktualniona historia Kamaszkina posłużyła Szynkariowowi do przedstawienia trudności z aklimatyzacją przeciętnego Rosjanina w poradzieckich realiach. Tłem fabuły jest „bandycki Petersburg”79, którym rządzą korupcja i bezprawie. Źródeł takiego stanu rzeczy należy upatrywać w latach transformacji ustrojowej, określanej dosadnymi epitetami, jak: „grabieżcza”, „gangsterska”, „mafijna”80. Sam Kazakow wspomina okres przejściowy jako czas sprawdzianu dla zaradności życiowej Rosjan. Dodaje jednak: jestem standardowym przyktadem, z okresu inkubacyjnego prosto do śmieci, nie wpisateś się w epokę $e^{81}$. Bohater nie może znaleźć dla siebie miejsca jako pisarz, nie interesują go tematy współcześnie chwytliwe, w literaturze dostrzega wyższy sens i ponadczasowe wartości. Dlatego najbardziej cenne są dla niego latami kolekcjonowane książki, które, jak sam zaznacza: w czasach radzieckich byty wielka wartościa (a teraz wielokrotnie opublikowanych nawet nie chca brać $w$ antykwariacie) ${ }^{82}$. Niewiele wiemy o jego literackiej karierze, poza opowiadaniem Samochód, które napisał z myślą o szybkim zarobku. Fabuła utworu wpisuje się w aktualne czasy i opowiada o urzędniku, który przeznaczył oszczędności życia na zamianę starego moskwicza na volvo. Finał historii sprowadza się do nagłej śmierci mężczyzny spowodowanej kradzieżą samochodu. Wasilij podkreśla, że jest to wariacja na temat Gogolowskiego „Szynelu’33, nie wiedząc, że wkrótce jego życie stanie się kolejnym remakiem klasycznej opowieści. Z pomocą włączenia w świat przedstawiony remake'u tekstu Gogola Szynkariow nakierował odbiorcę na jedną z możliwości odczytania Mieszkania. Zaakcentowanie obecności konkretnego obrazu literackiego pozwala głębiej wniknąć w sens opowiadania, dopowiedzieć jego zakończenie i wyeksponować kłopoty, z jakimi borykają się współcześni „mali ludzie”.

Brak stabilizacji finansowej to nie jedyny problem, z jakim styka się Kazakow. Mężczyzna zrozumial, że wartości, w które bezkrytycznie wierzył, w obecnym świecie niewiele znaczą. Uczucie żony wypaliło się wraz z odpływem gotówki, długoletnia przyjaźń została wystawiona na próbę z powodu utajnionej przeszłości Rogozina. Prawdopodobnie to właśnie fałszywy przyjaciel jest odpowiedzialny za nielegalną transakcję kupna mieszkania. Trwogę budzi też lokalne środowisko: większość znanych mu osób cierpi na chorobę alkoholową, młodzież nałogowo wącha klej. Wasilij uświadamia sobie, że przeprowadzka do nowego mieszkania jest jedynie próbą ucieczki od otaczającej go rzeczywistości, od której nie sposób uciec.

Remakiem opowieści Gogola nieodnoszącym się w sposób bezpośredni do współczesności jest dramat Baszmaczkin. Cud szynelu w jednym akcie. Bogajew należy do

Tamże, s. 184.

79 Bandycki Petersburg - tytuł książki Andrieja Konstantinowa i serialu telewizyjnego, emitowanego na kanale NTV w latach 2000-2007.

80 J. Smaga, Rosja w 20 stuleciu, Kraków 2002, s. 299.

81 V. Šinkarev, Kvartira..., s. 188.

82 Tamże, s. 164.

83 Tamże, s. 165. 
pokolenia młodych twórców rosyjskiej dramaturgii i wywodzi się ze „szkoły uralskiej”4. Autor, podobnie jak większość znanych uczestników seminarium dramaturgicznego Kolady, szczególną uwagą darzy twórczość autora Martwych dusz. Halina Mazurek zaznacza, że: Poprzez czeste nawiązania do dziet Gogola dramaturg zdaje się sugerować, że w naszych czasach ożyta tamta epoka, czas absurdów, samowoli, okropnych zjawisk, afer, lekceważenia cztowieka i czas totalnej znieczulicy ${ }^{85}$. Swoją fascynację klasykiem Bogajew zaprezentował w jednym z pierwszych tekstów - Martwe uszy. Najnowsza historia papieru toaletowego (Мертвые уши. Новейшая история туалетной бумаги, 1995). Pisarz chętnie opowiada, że fabuła kolejnej sztuki, poświęconej twórczości Gogola, powstała we śnie, jednak fakt ten był poprzedzony smutnymi wydarzeniami. Otóż po napisaniu Martwych uszu dramaturg zapadł na ciężką chorobę i trafił na kilka miesięcy do szpitala. Wspomina, że zajmował tóżko po zmarłym pacjencie A. A. Baszmaczkinie. Autor potraktował swoją chorobę jako karę i w owych ciężkich dniach podjął decyzję o rehabilitacji przed wielkim rosyjskim twórcą ${ }^{86}$. Nie sposób zweryfikować tej historii. Być może ma ona służyć uatrakcyjnieniu życiorysu dramaturga poprzez potwierdzenie faktu, że nierealne wydarzenia na naszych oczach splatają się z codziennością nie rzadziej niż w tekstach Gogola.

Fascynacja twórczością autora Rewizora ujawnia się na poziomie metody twórczej Bogajewa, w której dominującą rolę odgrywają ironia, specyficzny rodzaj humoru, groteska, fantastyka, gra słowem. Najczęściej bohaterami dramatów są współcześni „mali ludzie", wyróżniający się ekscentrycznym zachowaniem, zwiastującym obłęd. W sferze kreacji przypomina to Gogolowską niefantastyczną fantastykę. Świat fantastyki pochłania zdarzenia z realnej rzeczywistości, w której znajduje się bohater, co jest środkiem do ujawnienia prawdy o stanie ducha współczesnego „małego człowieka” ${ }^{87}$. Znamienną cechą dramaturgii Bogajewa jest także „śmiech przez łzy”, za pośrednictwem którego uczeń Kolady przedstawia tragizm życia ludzkiego.

Wszystkie wymienione cechy twórczości Bogajewa znajdują potwierdzenie w dramacie Baszmaczkin. Ścisła relacja utworu z pretekstem ujawnia się już na poziomie tytułu. Wykorzystanie nazwiska bohatera Szynelu to próba zwrócenia uwagi czytelnika na konkretną postać literacką, jej niepowtarzalność i unikalność. Zdaniem Olgi Troszynskiej świadczyć to może o zamiarze kanonizacji bohatera, co potwierdza podtytuł: Cud szynelu wjednym akcie $e^{88}$. Cud faktycznie się dzieje, bowiem szynel Kamaszkina ożywa i rozpoczyna mozolną wędrówkę po ulicach Petersburga w poszukiwaniu swojego właściciela. Bogajew nie poprzestaje na tytule i wprowadza kolejne odniesienia do tekstu Gogola.

84 „Szkoła uralska” - określenie grupy młodych dramaturgów związanych z Jekaterynburgiem i Nikołajem Koladą. Zob. H. Mazurek, Dramaturdzy z Jekaterynburga. „Szkota” Nikotaja Kolady, Katowice 2007.

85 Tamże, s. 26.

86 M. Černâk, S Gogolem na družeskoj noge. Ûbilejnye zametki, „Znamâ” 2009, nr 6, [online] http:// magazines.russ.ru/znamia/2009/6/ch14.html, 17 I 2017.

87 H. Mazurek, Dramaturdzy z Jekaterynburga..., s. 48-49.

88 O. Trošinskaâ, Strategiâ dopisyvaniâ povesti N.V. Gogolâ „Šinel” v p’ese O. Bogaeva „Bašmačkin”, „Vestnik Samarskogo gosudarstvennogo universiteta" 2011, nr 1-2, s. 158. 
Zamieszczone motto jest dosłownym cytatem z Szynelu: Zjawy, jedna dziwniejsza od drugiej, ukazywaty mu sięnieustannie, to mu się zwidywat Pietrowicz, u którego zamawiat szynel, z jakimiśsotrzaskami na ztodziejów zakradajacych mu się ustawicznie pod tózko, że wzywat co chwile gospodynię, aby wyciagnęta jednego z nich nawet spod kotdry ${ }^{89}$. Fragment archetekstu informuje czytelnika o stanie zdrowia bohatera, znajdującego się w halucynogennej gorączce. Przywidzenia i majaki Baszmaczkina są kluczem do rozszyfrowania tekstu Bogajewa. Na tym jednak nie koniec „namacalnych” relacji obu utworów. Pierwsza część dramatu to kolejny cytat z opowieści Gogola, traktujący o uczuciu strachu, jaki odczuwał Kamaszkin, stojąc na pustym placu na krótko przed kradzieżą ${ }^{90}$. Dalej następuje szczegółowy opis aktu napaści, przy czym dramaturg wprowadza imiona i biografie sprawców. Istotna cecha remake'u, jaką jest rozpoznawalność oryginału, jest na tyle oczywista w dramacie, że Bogajew zrezygnował z tekstu pobocznego i spisu postaci. Opierając się na terminologii Urickiego, Baszmaczkina można odnieść do p-remakeów, czyli adaptacji tekstów klasycznych, których prawidłowe odczytanie jest warunkowane znajomością archetekstu. Fabuła Szynelu jest niezbędna do zrozumienia utworu Bogajewa, bez niej dramat traci sens i wartość poznawczą. Właściwa akcja sztuki rozpoczyna się po utracie przez bohatera płaszcza. $Z$ tego względu dramat może być włączony do kategorii remake’ów-sequeli. Ilja Gubin określa także utwór jako remake-motyw, czyli nową interpretację klasycznego motywu literackiego ${ }^{91}$. Najważniejszą kwestią pozostaje znieczulica i bezduszność oraz obrona przed nimi „małego człowieka”. Paradoksalnie dusza ożywa w szynelu, z nadprzyrodzoną siłą wymierzającym sprawiedliwość wszystkim, którzy skrzywdzili i nadal krzywdzą Baszmaczkina.

Akcja utworu rozgrywa się na dwóch przenikających się płaszczyznach: realistycznej i fantastycznej. Pogrążony w malignie Baszmaczkin, obserwujący wędrówkę szynelu, jest częścią linii realistycznej. Bohater odzwierciedla Gogolowski pierwowzór. Podobnie jak w Szynelu, w chorobie opiekuje się nim gospodyni, zaś wezwany lekarz oznajmia rychły zgon. Rozszerzony został natomiast opis stanu duszy postaci. Chaotyczne myśli Baszmaczkina krążą wokół utraconego płaszcza: A co gdyby rzeczywiście... Mój szynel ożyt i sam... sam zacząt mnie szukać. Przyszedtby i powiedziat: „Witaj, mój mity Baszmaczkinie, to ja, twój szynel. Znalaztem cię". (Zamyka oczy) ${ }^{92}$. Niezależnie od majaczeń bohatera, szynel rozpoczął już poszukiwania prawomocnego właściciela. Jest to główna oś tematyczna utworu, rozgrywająca się na płaszczyźnie fantastycznej. Metaforyka zdesperowanego płaszcza, który miota się po stołecznym mieście, jest nader czytelna. Szynel, przywiązany do swojego gospodarza, nic bez niego nie znaczy. Jest pustą formą bez treści. Motyw zagubionej ludzkiej duszy dotyczy całego Petersburga. Zdezorientowany portier próbujący odnaleźć Baszmaczkina wykrzykuje znaczące słowa: Petersburg to wielkie miasto, cztowieka nie znajdziesz ${ }^{93}$. Szynel krąży po mieście martwych

\footnotetext{
89 O. Bogaev, Bašmačkin..., s. 366. Por. M. Gogol, Szynel..., s. 186.

90 M. Gogol, Szynel..., s. 179.

$91 \quad$ I. Gubin, Rimejk kak tendenciâ...

92 O. Bogaev, Bašmačkin..., s. 379.

93 Tamże, s. 419.
} 
dusz, stykając się na każdym kroku z otępieniem, bezdusznością, uzależnieniem od rutyny i automatyzmem ludzkich zachowań. W ten sposób Bogajew daje do zrozumienia, że świat stał się „szynelem”, zaś dusza człowieka jest ulotną treścią. Dlatego więcej oznak człowieczeństwa przejawia przedmiot, który przejmuje ludzkie cechy. Treść dramatu potwierdza autorska myśl: prędzej ożywi się i okaże wzruszenie to, co z natury martwe, niż cztowiek, którego nie porusza nawet mówiący ludzkim gtosem ptaszcz ${ }^{94}$.

Absurdalna wędrówka szynelu jest nie tylko próbą odnalezienia Baszmaczkina, ale ma również na celu wymierzenie sprawiedliwości. Płaszcz został obdarzony magiczną mocą unicestwiania wszystkich, którzy przyczynili się do udręki Akakiusza. Tragiczna śmierć dotyka ludzi wasatych ${ }^{95}$, Tichona i Jegora, drobnych złodziei, będących oprawcami Baszmaczkina. Jednak żądza zemsty rozprzestrzenia się i prowadzi do śmierci wszystkich postaci, które nie chcą pomóc w poszukiwaniach właściciela. Tragicznie giną dziennikarz i redaktor gazety, do których szynel zwrócił się z prośbą o odnalezienie Baszmaczkina. Absurdalną śmiercią umiera bogata wdowa, pragnąca zatrzymać „ożywioną część garderoby”. Ofiarami stają się także wszyscy, którzy próbują w całej sytuacji znaleźć jakąś korzyść materialną dla siebie: inżynier, stróż, żona krawca, dzielnicowy, urzędnik w biurze rzeczy znalezionych. Zło mnoży się, jak gdyby za sprawą kropli krwi bohatera zastygłej na kołnierzu płaszcza. Szynel występuje w roli sobowtóra Gogolowskiego Kamaszkina i w jego imieniu mści się za doznaną krzywdę.

Zarówno szynel, jak i jego właściciel zostają sami ze swoim problemem. Ich cierpienia mają jednak różny wymiar. Przemierzając ulice Petersburga, płaszcz cierpi „aktywnie". Płacze, jęczy, zawodzi, nawołuje swojego właściciela. Baszmaczkin natomiast przeżywa cierpienie w sposób bierny. Pragnie odzyskać szynel, jednak stan jego zdrowia nie pozwala mu na podjęcie działań. Zmagania płaszcza obserwuje z pozycji horyzontalnej. Zamknięta przestrzeń pokoju rozszerza się w wyobraźni umierającego bohatera na topografię całego Petersburga. Etapy wędrówki szynelu ukazują się Baszmaczkinowi kolejno w kałamarzu, damskiej torebce, bucie, pod prześcieradłem. Wydaje się, że to chorobowe halucynacje bohatera napędzają dalszy rozwój akcji, rozgrywający się na płaszczyźnie fantastycznej. Finałowa scena dramatu, w której bohater umiera, gładząc rękaw odzyskanego szynelu, stanowi o ostatecznym połączeniu splecionych ze sobą płaszczyzn utworu. Przedmiot wrócił do właściciela, dusza połączyła się z ciałem, dzięki czemu Baszmaczkin odnalazł spokój. Jego śmierć jest wyzwoleniem od cierpienia, jakiego doświadczył w mrocznym Petersburgu. Długo oczekiwany kres męki symbolizuje dziecięcy uśmiech na twarzy bohatera. Pewnie zobaczyt przed śmiercia aniota - mówi jeden z mężczyzn, szykujących zmarłego do pochówku. W roli anioła objawił się szynel, jednak można dodać, że był to „anioł upadły”, skoro na swej drodze siał śmierć i zniszczenie. Ciemność i cisza stanowiące tło ostatniej części dramatu sugerują, że umarł ostatni „mały człowiek”, któremu za życia nikt nie okazał szacunku poza ożywionym szynelem.

Jak zostało wspomniane, dramat Bogajewa został sklasyfikowany jako remake-sequel i remake-motyw. Troszynska wskazuje także na cechy remake'u-kontaminacji,

94 H. Mazurek, Dramaturdzy z Jekaterynburga..., s. 28.

95 M. Gogol, Szynel..., s. 179. 
a więc kompilacji kilku motywów, zaczerpniętych z Opowieści petersburskich ${ }^{96}$. W chorobowych halucynacjach Baszmaczkina można dostrzec szaleństwo Popryszczyna z Pamiętnika szaleńca (Записки сумасшедшого, 1935). Wskazuje na to fragment, w którym szynel w odpowiedzi na pytanie cara, czy wie, kto jest Imperatorem Rosji, bez cienia zastanowienia odpowiada: Baszmaczkin ${ }^{97}$. Sam Akakiusz w pewnym momencie odczuwa swoją wielkość, majacząc: Czy to oznacza, że ja, Akakiusz Baszmaczkin, statem się wielkim? [...] Czy to w ogóle możliwe? Akakiusz Akakiuszowicz nie pisarz, a sam Leksander Macedoński ${ }^{98}$. Z kolei motyw wędrówki szynelu można odczytać jako bezpośrednie odwołanie do opowieści Gogola Nos (Hoc, 1836). Szczególnie scena w redakcji petersburskiej gazety świadczy o zapożyczonym wątku z historii majora Kowalowa, który utracił narząd węchu. Żądza zemsty, jaką kieruje się ożywiony szynel, przywołuje treść utworu Gogola Portret (Портрет, 1837 - II wersja), w którym obraz przynoszący bogactwo jest jednocześnie sprawcą nieszczęść. Za pośrednictwem Gogolowskiego tematu Bogajew wyraźnie daje do zrozumienia, że dobrobyt materialny i kult przedmiotów nie dają szczęścia. Przeciwnie, prowadzą do duchowej pustki i utraty człowieczeństwa. I wreszcie obraz samego Petersburga odnosi czytelnika do Newskiego Prospektu (Невский Проспект, 1835). Chłodne, wietrzne, oblodzone miasto staje się główną przyczyną zarówno tragedii Baszmaczkina, jak i udręką przemierzającego je płaszcza. W zimowej petersburskiej aurze łatwo można pomylić człowieka z szynelem. Niszczycielska siła, tkwiąca w stolicy, gubi naturalne piękno człowieka, przywodzi do utraty istoty człowieczeństwa oraz szaleństwa ${ }^{99}$.

Jak widać, dramat Bogajewa jest znaczeniowo napełniony bogactwem treści. Dramaturg aktualizuje Gogolowskie motywy (strachu, władzy, godności „małego człowieka", niszczycielskiej siły rządzącej Petersburgiem). Jest to rodzaj swoistej gry z pretekstem, próba odkodowania klasyki i dopowiedzenia historii przemilczanej przez Gogola. Jednak sztuka ma także wymiar uniwersalny i kieruje w stronę ponadczasowych wartości, jak: miłosierdzie, dobro, humanizm, idea przebaczenia. Za pośrednictwem remake'u autor wyraża dezaprobatę dla niepoddającego się przemianom schematu zachowań, stosunków międzyludzkich i niezmiennych stereotypów opierających się na wrogości i bezduszności. Dramat jest odniesieniem do życia codziennego w naszej cywilizacji, w której stan posiadania i gra pozorów są ważniejsze od podstawowych wartości $^{100}$. Nie ma tu miejsca na szczerość, współczucie i troskę o drugiego człowieka, czemu sprzeciwia się dramaturg w swojej twórczości.

Zaproponowana analiza wybranych rosyjskich remake'ów wskazuje na liczne sposoby innowacji klasycznych tekstów literatury, jakie umożliwia ten typ adaptacji. Jedną

96 O. Trošinskaâ, Strategiâ dopisyvaniâ povesti..., s. 161.

97 O. Bogaev, Bašmačkin..., s. 414 .

98 Tamże, s. 403.

99 Zob. M. Kowalska, „Genius loci” Petersburga w świetle „Opowieści petersburskich” Mikotaja Gogola, [w:] $W$ kręgu problemów antropologii literatury. W stronę antropologii niezwyktości, red. W. Supa, Białystok 2013, s. 328-341.

100 H. Mazurek, Dramaturdzy z Jekaterynburga..., s. 28. 
z ważniejszych funkcji remake’u jest aktualizacja znanych motywów literackich. Za pośrednictwem Szynelu w zaproponowanych utworach wraca zagadnienie „małego człowieka”, problem jego godności i obrony przed bezdusznym otoczeniem. Ten typ bohatera literackiego jest wciąż obecny w kolejnych stuleciach, o czym świadczy historia Rachlina i Aleksieja Aleksiejewicza. Powraca także temat rosyjskiego biurokratyzmu i antyhumanitarnego charakteru systemu, których rozrost w czasach radzieckich opisał Wojnowicz. Zagrożenie, jakie niesie złudna pogoń za wartościami materialnymi, to wciąż aktualne zagadnienie, szczególnie w dobie konsumpcjonizmu, o czym przypomina Gorczew. Oryginalne podejście do archetekstu przedstawił Bogajew, kreśląc historię umierającego Baszmaczkina. W wyniku postmodernistycznej gry z klasyką autor nie tylko uaktualnił jej treść, ale i dopisał niedopowiedzianą fabułę Gogolowskiej opowieści, nadając jej nowe znaczenie.

Poprzez tekst klasyczny twórcy remakeów zwracają uwagę na problemy współczesności. Wojnowicz przedstawił piramidę zniewolonych twórców literatury czasów radzieckich. Autor wniknął w mechanizmy funkcjonowania Związku Pisarzy oraz wnikliwie opisał cenę, jaką płaci się za przynależność do tej instytucji. Gorczew, zamieniając szynel na telefon komórkowy, uwypuklił problem bezprawia i korupcji w rosyjskich służbach mundurowych. Szynkariow w Mieszkaniu również ukazał bezdroża bezprawia w Rosji, uderzające w „małego człowieka”, idealistę nieprzystającego do nowych czasów. Z kolei Bogajew, kontynuując XIX-wieczną fabułę Szynelu, zwrócił uwagę na samotność jednostki w tłumie, utratę człowieczeństwa i zanik ponadczasowych wartości.

Tym, co łączy wymienione remaki, są ironia, groteska i absurd. Pod tym względem utwory można rozpatrywać jako przedłużenie Gogolowskiego „śmiechu przez łzy”. Ponadto bohaterowie każdego $\mathrm{z}$ analizowanych tekstów, w mniejszym bądź większym stopniu, noszą znamiona obłędu. Motyw szaleństwa jest wpisany w twórczość Gogola, co szczególnie mocno zostało uwypuklone w Pamiętniku szaleńca ${ }^{101}$. Współczesny bohater także nie znajduje ucieczki przed chorobą psychiczną, na co wpływ mają czasy, w jakich przyszło mu egzystować.

W związku ze stwierdzeniem, że klasyka jest bezbronna wobec takich praktyk jak remake ${ }^{102}$, zasadnym jest trwający spór krytyków literackich o miejsce tej formy adaptacji we współczesnej literaturze. Jednak każda przeróbka jest lepsza od losu dzieł rosyjskich klasyków, przedstawionego w dramacie Bogajewa Martwe uszy. W wyniku braku zainteresowania klasyką, podniszczone woluminy mają zostać spalone lub przetworzone na papier toaletowy. Remake należy więc potraktować jako ubogacający dialog z klasyką, który przywraca jej należne miejsce i nie pozwala o niej zapomnieć.

101 Zob. więcej: B. Brążkiewicz, Choroba psychiczna w literaturze i kulturze rosyjskiej, Kraków 2011, s. 165-169.

102 M. Zagidullina, Remejki, ilin... 


\section{BIBLIOGRAFIA}

Amal'rik A., Prosuŝestvuet li Sovetskij Soûz do 1984?, [online] http://www.vehi.net/politika/ amalrik.html.

Amal'rik A., Zapiski dissidenta, Moskva 1991.

Bahtin M., Voprosy literatury i èstetiki. Issledovaniâ raznyh let, Moskva 1975.

Balbus S., Między stylami, Kraków 1996.

Barański J., Świat rzeczy. Zarys antropologiczny, Kraków 2007.

Bogaev O., Bašmackkin. Čudo šineli v odnom dejstvii, [w:] tenże, Russkaâ narodnaâ počta. 13 komedij, Ekaterinburg 2012.

Brążkiewicz B., Choroba psychiczna w literaturze i kulturze rosyjskiej, Kraków 2011.

Černâk M., S Gogolem na družeskoj noge. Ûbilejnye zametki, „Znamâ” 2009, nr 6, [online] http://magazines.russ.ru/znamia/2009/6/ch14.html.

Culler J., Presupozycje i intertekstualność, przeł. K. Rosner, Warszawa-Wrocław 1980.

Dudek A., Wtadimira Wojnowicza odkrywanie zamystu, czyli „życie jakie jest”, [w:] Realiści i postmoderniśsi. Sylwetki wspótczesnych rosyjskich pisarzy emigracyjnych, red. L. Suchanek, Kraków 1997.

Eco U., Dopiski na marginesie „Imienia róży”, [w:] tenże, Imięróży, przeł. A. Szymanowski, Warszawa 1987.

Eco U., Innowacja i powtórzenie. Pomiędzy modernistyczna i postmodernistyczna estetyką, przeł. T. Rutkowska, „Przekazy i Opinie” 1990, nr 1-2.

Elzenberg H., Wartość i cztowiek. Rozprawy z humanistyki i filozofii, Toruń 2005.

Federal'nyj zakon ot 7 fevralâ 2011 g. N 3-FZ „O policii”, ,Rossijskaâ gazeta. Federal'nyj vypusk” 2011, nr 5401 (25), [online] https://rg.ru/2011/02/07/police-dok.html.

Galster B., Wstęp, [w:] M. Gogol, Opowieści, oprac. B. Galster, przeł. J. Wyszomirski, J. Tuwim, J. Brzęczkowski, Wrocław 1972.

Genette G., Palimpsesty. Literatura drugiego stopnia, przeł. T. Stróżyński, A. Milecki, Gdańsk 2014.

Głowiński M., Intertekstualność, groteska, parabola. Szkice ogólne i interpretacje, Kraków 2000.

Gogol M., Szynel, przeł. J. Wyszomirski, [w:] tenże, Opowieści, oprac. B. Galster, przeł. J. Wyszomirski, J. Tuwim, J. Brzęczkowski, Wrocław 1972.

Gorčev D., Telefon, [w:] tenże, Dikâa žizn' Gondvany, [online] http://e-libra.ru/books/198560-dikaya-zhizn-gondvany.html.

Gubin I., Rimejk kak tendenciâ (slučaj Olega Bogaeva), [online] http://litbook.ru/article /4164/.

Hlopin A., Fenomen dvoemysliâ. Zapad i Rossiâ (osobennosti rolevogo povedeniâ), [online] http://ecsocman.hse.ru/data/157/463/1217/005Hlopin.pdf.

Indeks doveriâ policii, [online] http://www.levada.ru/2013/03/04/indeks-doveriya-politsii.

Kowalska M., „Genius loci” Petersburga w świetle „Opowieści petersburskich” Mikotaja Gogola, [w:] $W$ kregu problemów antropologii literatury. W stronę antropologii niezwyktości, red. W. Supa, Białystok 2013.

Krajewski M., Przedmiot, który ucztowiecza..., „Kultura Współczesna” 2008, nr 3. 
Łotman J., Ludzie i stopnie, [w:] tenże, Rosja i znaki. Kultura szlachecka w wieku XVIII i na początku XIX, przeł. B. Żyłko, Gdańsk 2009.

Markiewicz H., Odmiany intertekstualności, [w:] tenże, Literaturoznawstwo i jego sasiedztwa, Warszawa 1989.

Maroń A., Remejk kak forma sozdania avtorskogo mira v p’esah Nikolaa Kolady (kvoprosu o puskinskom i gogolevs), „Slavia Orientalis” 2012, nr 2.

Mazurek H., Dramaturdzy z Jekaterynburga. „Szkota” Nikotaja Kolady, Katowice 2007.

Nefagina G., Rimejk v sovremennoj russkoj proze, [w:] Vzaimodejstvie literatur v mirovom slavânskom processe, Grodno 1996.

Nefagina G., Russkaâ proza konca HH veka, Moskva 2003.

Nycz R., Parodia i pastisz. Z dziejów pojęć artystycznych w świadomości literackiej XX wieku, [w:] tenże, Tekstowy świat. Poststrukturalizm a wiedza o literaturze, Warszawa 1993.

O reforme milicii, [online] http://www.levada.ru/2011/02/23/o-reforme-militsii.

Pańkowska E., Twórczość Wtadimira Wojnowicza, Białystok 2009.

Pietrzycka-Bohosiewicz K., Historia zapisana w cztowieku... Wybrane problemy wolnej literatury rosyjskiej, Kraków 2008.

Problema bezopasnosti, kačestvo raboty policii (milicii) $i$ otnošenie $k$ smertnoj kazni v Bolgarii, Cehii, Bengrii, Litve, Pol’se i Rossii, [online] http://www.levada.ru/2002/08/04/problema-bezopasnosti-kachestvo-raboty-politsii-militsii-i-otnoshenie-k-smertnoj-kazni-v-bolgariichehii-vengrii-litve-polshe-i-rossii.

Radziwinowicz W., Pan Policjant, „Gazeta Wyborcza” 2011, 11 II, [online] http://wyborcza. pl/1,76842,9086812,Pan_Policjant.html.

Rakowski T., Antropologia rzeczy. Wprowadzenie, „Kultura Współczesna” 2008, nr 3.

Remake, [w:] Stownik jezyka polskiego, [online] http://sjp.pwn.pl/szukaj/remake.html.

Remake, [w:] W. Kopaliński, Stownik wyrazów obcojęzycznych $i$ zwrotów obcojezycznych z almanachem, cz. 2, Warszawa 2007.

Rimejk, [w:] L. Krysin, Tolkovyj slovar' inostrannyh slov, Moskva 2007.

Rybal'čenko T., Žizn' kanona v raznyh formah apellâcii k russkoj klassike sovremennyh russkih pisatelej (stilizaciâ, metateksty, dekonstrukciâ, rimejk i pr.), „Toronto Slavic Quarterly” 2013, $\mathrm{nr}$ 44, [online] http://sites.utoronto.ca/tsq/44/tsq44_rybalchenko.pdf.

Ŝerbino K., Polâkovskij V., Recenziâ na knigu: Gorčev D. „Dikaâ žizn’ Gondvany”, „Novoe Literaturnoe Obozrenie” 2009, nr 95, [online] http://magazines.russ.ru/nlo/2009/95/ po20.html.

Šinkarev V., Kvartira, [w:] Novye peterburgskie povesti, red. P. Krusanov, Sankt Peterburg 2006. Smaga J., Rosja w 20 stuleciu, Kraków 2002.

Smirnov C., Rimejk (parafraza) v „novoj russkoj” drame, [online] http://mion.isu.ru/filearchive/mion_publcations/sbornik_Sib/6_2.html.

Suchanek L., Świadkowie, oskarżyciele, sprzymierzeńcy i obrońcy. O postawach pisarzy rosyjskich, [w:] Dać świadectwo prawdzie. Portrety wspótczesnych pisarzy rosyjskich, red. L. Suchanek, Kraków 1996.

Tarazevič E., Rimejk v sovremennoj russkoj dramaturgii, [w:] Sovremennaâ russkaâ literatura. Problemy izučeniâ i prepodavaniâ. Materialy Meždunarodnoj naučno-praktičeskoj konferencii, Perm' 2006. 
Trošinskaâ O., Strategiâ dopisyvaniâ povesti N.V. Gogolâ „Šinel”” v p’ese O. Bogaeva „Bašmačkin”, „Vestnik Samarskogo gosudarstvennogo universiteta” 2011, nr 1-2.

Urickij A., Dubl'vtoroj, „Družba narodov” 2002, nr 3, [online] http://magazines.russ.ru/ druzhba/2002/3/ur.html.

Wojnowicz W., Czapka, przeł. E. Desperak, Warszawa 1990.

Zagidullina M., Remejki, ili Ėkspansiâ klassiki, „Novoe Literaturnoe Obozrenie” 2004, nr 69, [online] http://magazines.russ.ru/nlo/2004/69/za13.html.

Martyna KOWALSKA - doktor nauk humanistycznych w zakresie literaturoznawstwa, kulturoznawca, rosjoznawca; adiunkt w Instytucie Rosji i Europy Wschodniej UJ; członek Komisji Kultury Słowian PAU. Zajmuje się rosyjską kulturą i literaturą XX-XXI wieku, zjawiskiem dysydentyzmu i ,inakomyslija”, pisarstwem kobiet w Rosji, a także kulturowymi ruchami młodzieżowymi w Federacji Rosyjskiej. Autorka monografii Aleksander Sotżenicyn. Homo sovieticus i cztowiek sprawiedliwy (Torun 2011) i kilkudziesięciu artykułów naukowych o tematyce rosjoznawczej (ORCID: 0000-00022349-3050). 